\title{
RUMINAL DEGRADABILITY OF HARD OR SOFT TEXTURE CORN GRAIN AT THREE MATURITY STAGES
}

\author{
Marcos Neves Pereira ${ }^{1 *}$; Renzo Garcia Von Pinho²; Ralph Guilherme da Silva Bruno; Gabriela \\ Arruda Calestine ${ }^{1}$ \\ ${ }^{1}$ Universidade Federal de Lavras - Depto. de Zootecnia, C.P. 37 - 37200-000, Lavras, MG - Brasil. \\ ${ }^{2}$ Universidade Federal de Lavras - Depto. de Agricultura. \\ *Corresponding author <mpereira@ufla.br>
}

\begin{abstract}
The predominance of vitreous endosperm in hard texture flint corn (Zea mays L.) can decrease ruminal starch digestion comparatively to the farinaceous endosperm of dent corn, reducing energy content of the grain. The objective of this experiment was to evaluate the effects of texture and maturity stage on ruminal degradability of corn grain. Two dent and two flint hybrids were harvested at the early dent, half milk line, and black layer stages. The proportion of vitreous endosperm (vitreousness) in dent hybrids was $44.3 \%$, while in flint it was $67.0 \%$. There was a linear increase in vitreousness with advancing maturity. Flint hybrids at the early dent stage were more vitreous than dent at the black layer stage. The increase in vitreousness per maturation day was greater for flint hybrids. Grains were incubated in situ in the rumen of 6 cows. The 24-hour ruminal dry matter degradation was $63.3 \%$ for dent corn and $52.4 \%$ for flint corn. The 72 -hour incubation residues of dent and flint hybrids were $7.6 \%$ and $15.6 \%$, respectively. Ruminal degradability was similar between hybrids at the early dent and half milk line stages. There was a marked texture effect on ruminal degradability at the black layer stage (quadratic effect of maturity stage and interaction between texture and maturity stage). Use of dent hybrids, compared to flint hybrids, may result in smaller relative reduction in ruminal starch digestion in situations of late grain harvesting.

Key words: vitreousness, endosperm, dent corn, flint corn, rumen

\section{DEGRADABILIDADE RUMINAL DE GRÃOS DE MILHO DE TEXTURA DURA OU MACIA EM TRÊS ESTÁDIOS DE MATURAÇÃO}

\begin{abstract}
RESUMO: A predominância de endosperma vítreo em milho (Zea mays L.) flint de textura dura pode deprimir a digestão ruminal do amido comparativamente ao endosperma farináceo de milho dentado, reduzindo o conteúdo energético do grão. O objetivo deste experimento foi avaliar os efeitos da textura e do estádio de maturidade sobre a degradabilidade ruminal de grãos de milho. Dois híbridos dentados e dois duros foram colhidos nos estádios dentado inicial, metade da linha do leite e linha preta. A proporção de endosperma vítreo (vitreosidade) dos híbridos dentados foi 44,3\% e a dos duros foi 67,0\%. Ocorreu aumento linear na vitreosidade com o avançar da maturidade. Os híbridos duros no estádio dentado inicial foram mais vítreos que os dentados no estádio linha preta. O aumento na vitreosidade por dia de maturação foi maior nos híbridos duros. Os grãos foram incubados in situ no rúmen de 6 vacas. A degradação ruminal da matéria seca em 24 horas foi 63,3\% nos grãos dentados e 52,4\% nos duros. O resíduo após 72 horas de incubação de híbridos dentados e duros foram 7,6\% e 15,6\%, respectivamente. A degradabilidade ruminal dos híbridos foi similar nos estádios dentado inicial e metade da linha do leite. $\mathrm{O}$ efeito da textura sobre a degradabilidade ruminal foi acentuado no estádio linha preta $(P<0,01$ para o efeito quadrático de estádio de maturação e para a interação entre textura e estádio de maturação). A utilização de híbridos dentados, comparativamente a híbridos duros, pode resultar em menor queda relativa na digestão ruminal do amido em situações de colheita tardia dos grãos.

Palavras-chave: vitreosidade, endosperma, milho dentado, milho flint, rúmen
\end{abstract}

\section{INTRODUCTION}

High energetic value resulting from low fiber content, high dry matter yield per unit area, easy mechanical harvesting and good silage fermentation pattern without the need for additives or wilting are characteristics that make the corn plant one of the most utilized forages for dairy cattle in Brazil. Ruminal degradability of grain non-fibrous carbohydrates determines the energy value of this feed (Allen et al., 1997).

The texture of the corn grain is determined by the amount of vitreous endosperm proportionally to the farinaceous endosperm (Watson, 1988). In Brazil, the corn seed industry has opted for hard texture hybrids, in which high vitreousness endosperms are predominant. The vitreous endosperm is hard and crystalline, possesses a con- 
tinuous and abundant protein matrix, with larger and more numerous protein bodies, and compact and polygonal starch granules. In the farinaceous endosperm, which is opaque and soft-textured, the protein matrix is discontinuous and has few protein bodies, and the starch granules are spherical, larger, less aggregated and surrounded by air spaces (Robutti et al., 1974; Pratt et al., 1995). The protein matrix seems to limit the enzymatic digestion of starch in cereals (Kotarski et al., 1992) and is responsible for differences in ruminal degradability of grains (McAllister et al., 1993; Rooney \& Pflugfelder, 1986). There is evidence that hard-textured corn grain is less degraded in the rumen than soft grain (Philippeau \& Michalet-Doreau, 1997).

Forage maturity stage also determines silage quality (Johnson et al., 1999). As it advances in maturity, the corn plant accumulates starch and, by dilution, its fiber content is reduced. After the point for ideal ensilingis reached, starch digestibility decreases, thus reducing the energy value of the silage (Bal et al., 1997). As the plant progresses in age, reduction in grain ruminal degradability has been found to be greater for flint than for farinaceous hybrids (Philippeau \& Michalet-Doreau, 1997). Hard texture hybrids, prevalent in the Brazilian market, may have accentuated reduction in ruminal degradability under late ensiling situations. After these considerations, the objective of this study was to evaluate the effects of corn grain texture and plant maturity stage on ruminal degradability of the grain from hybrids available in the Brazilian market.

\section{MATERIAL AND METHODS}

Four corn hybrids were used in this study: two with hard texture grain (AG 9012, Sementes Agroceres, Uberlândia, MG; Tork, Syngenta Seeds, Uberlândia, MG) and two with soft texture grain (AG 1051 and AG 4051, Sementes Agroceres, Uberlândia, MG) (Table 1). The hybrids were planted on November 8, 1999, and grown on ten, $7-\mathrm{m}$ long rows, spaced by $0.8 \mathrm{~m}$, at a seeding density designed to obtain 55,000 plants per hectare. The soil was cultivated according to conventional procedures: plowing at a $0.3 \mathrm{~m}$ depth, followed by two harrowings to break clods and level the terrain. At seeding time, 400 $\mathrm{kg} \mathrm{ha}^{-1}$ of the $08-28-16$ rate $+0.5 \% \mathrm{Zn}$ were applied. Sidedressing fertilization was done with $60 \mathrm{~kg} \mathrm{ha}^{-1}$ nitrogen (urea) and $50 \mathrm{~kg} \mathrm{ha}^{-1} \mathrm{~K}_{2} \mathrm{O}$ when plants reached between four and five leaves. A second sidedressing fertilization was done when plants reached between eight and nine leaves, with $60 \mathrm{~kg} \mathrm{ha}^{-1}$ nitrogen (urea).

The hybrids were harvested at three maturity stages defined by the milk line position in the grain: early dent (ED), half milk line (ML) and black layer (BL). A 2 $\times 3$ factorial arrangement of treatments was defined, with two textures (flint and dent) and three grain maturity stages (ED, ML, BL). Grain harvest point (Table 2) was defined by visual evaluation starting 20 days after flowering. Visual evaluation of the ED stage was performed every five days, by randomly husking three ears without removing them from the plant to observe how dented was the grain. Ten days after harvesting the ED stage, visual evaluations were performed every two days by breaking one ear in half, until the ML stage was reached. The same method used for the ML stage was utilized for the BL stage.

For each hybrid, at each maturity stage, a $5 \mathrm{~m}$ row was harvested, after disregarding $1 \mathrm{~m}$ at each end of the row, and six ears were randomly selected and threshed by hand. Grains were frozen-sectioned with a scalpel. Each kernel was cut into four parts to simulate the ensiling process. Eight grams of original matter from sectioned grains were placed into polyester bags measuring $9 \times 15 \mathrm{~cm}$ for in situ ruminal degradation.

In order to evaluate in situ degradability, six nonlactating, non-pregnant, rumen cannulated cows were utilized. One week prior to the beginning of the incubations and during the experimental period, the animals received a diet consisting of chopped sugarcane ad libitum and 4 $\mathrm{kg}$ of a corn-soybean meal concentrate fed twice a day.

The four corn hybrids at three maturity stages were simultaneously incubated in the rumen of the six animals. Bags were incubated for $24 \mathrm{~h}$ to estimate the effective dry matter degradability in the rumen and for 72 $\mathrm{h}$ to obtain an estimate of the undigestible fraction. In addition to the polyester bags containing each treatment, an empty bag (blank) was simultaneously incubated at each time to estimate microbial dry matter contamination. Bags corresponding to each cow at each incubation time were placed into a laundry bag $(0.40 \times 0.40 \mathrm{~m})$ containing 500 $\mathrm{g}$ of lead. The laundry bags, zipper-locked and attached to a double, 1-m long nylon cord, were fixed to the external flange of the rumen cannula. Before ruminal incu-

Table 1 - Hybrid characteristics according to specifications of the manufacturing companies.

\begin{tabular}{lccc}
\hline Hybrid & Cycle & $\begin{array}{c}\text { Temperature } \\
\text { sum }^{1}\end{array}$ & $\begin{array}{c}\text { Type of grain and } \\
\text { coloration }\end{array}$ \\
\hline Agroceres 1051 & Normal & 863 & Dent, yellow \\
Agroceres 4051 & Normal & 892 & Dent, yellow/cream \\
Agroceres 9012 & Super-early & 833 & Flint, reddish \\
Tork & Early & 860 & Flint, reddish \\
\hline
\end{tabular}

${ }^{1}$ Temperature sum=sum of caloric units needed for flowering

Table 2 - Age of corn hybrids at each maturity.

\begin{tabular}{lccc}
\hline & Early dent & $1 / 2$ milk line & Black layer \\
\cline { 2 - 4 } & \multicolumn{3}{c}{ days after planting } \\
\hline Agroceres 1051 & 134 & 155 & 169 \\
Agroceres 4051 & 134 & 151 & 167 \\
Agroceres 9012 & 134 & 147 & 162 \\
Tork & 134 & 147 & 162 \\
\hline
\end{tabular}


bation samples were immersed in water at room temperature. Samples incubated for $72 \mathrm{~h}$ were placed in the rumen before the $24 \mathrm{~h}$ incubated bags. Samples were all removed from the rumen at the same time, immersed in water containing ice cubes, and then frozen at $-20^{\circ} \mathrm{C}$.

Upon thawing, the incubated and blank bags were machine-washed under constant water flow until the water came out clear. The dry matter inserted in the rumen and the incubation residue were determined by drying the sectioned grain (\%DM) and the incubated bags, respectively, in a forced-ventilation oven at $55^{\circ} \mathrm{C}$ for $48 \mathrm{~h}$. Microbial contamination per gram of bag was calculated and deducted from each incubation residue proportionally to the weight of the corresponding bag. The dry matter degradation in $24 \mathrm{~h}$ (DEG24) and the residue at $72 \mathrm{~h}$ of incubation (RES72) were calculated and expressed as percentages of the initial dry matter.

One hundred grains of each hybrid at each maturity stage were randomly selected and used to determine the vitreousness (Vitre). Among those 100 grains, 10 groups of 10 grains visualy homogeneous in size and shape were formed. From each of those 10 groups, one grain was randomly sampled. A composite sample was then formed with 10 grains from each hybrid, at each stage. The sample was immersed in water for approximately $3 \mathrm{~min}$, and after that the grains were dried with a paper towel and the pericarp and germ were separated from the endosperm by dissection with a scalpel. The dissected endosperm was kept at room temperature for 24 hours and then weighed. Next, the vitreous endosperm was separated from the farinaceous endosperm by dissection with a scalpel. The weight of vitreous endosperm was determined and expressed as percentage of the total endosperm weight (Dombrink-Kurtzman \& Bietz, 1993).

\section{Statistical Analysis}

The variables DEG24 and RES72 were analyzed with the GLM procedure of the SAS statistical package (SAS Institute Inc., 1988) by the following model:

$$
\mathrm{Y}_{\mathrm{ijk}}=\mu+\mathrm{V}_{\mathrm{i}}+\mathrm{T}_{\mathrm{j}}+\mathrm{M}_{\mathrm{k}}+\mathrm{TM}_{\mathrm{jk}}+\mathrm{e}_{\mathrm{ijk}}
$$

where: $\mu$ = overall mean; $V_{i}=$ cow effect ( $i=1$ to 6 ); $T_{j}$ = grain texture effect $(\mathrm{j}=$ flint, dent $) ; \mathrm{M}_{\mathrm{k}}=$ maturity stage effect $(\mathrm{k}=\mathrm{ED}, \mathrm{ML}, \mathrm{BL}) ; \mathrm{TM}_{\mathrm{jk}}=$ interaction between grain texture and maturity stage; $\mathrm{e}_{\mathrm{ijk}}=$ residual error, assumed to be identically and randomly distributed in a normal distribution with mean $\mu$ and variance $\sigma^{2}$.

Vitre and \%DM were analyzed by an identical model without the cow effect. Two orthogonal contrasts with 1 degree of freedom were tested for the maturity stage effect of the grain: linear effect of maturation (ED versus BL) and quadratic effect of maturation (ML versus ED+BL). Regressions between the studied variables and plant age, and between DEG24 and \%DM were run with data from each hybrid, at each maturity stage.

\section{RESULTS AND DISCUSSION}

The Brazilian population of commercial corn hybrids consists of materials predominantly of hard texture (Cruz et al., 2003). Therefore, it is important to define, within this population, the vitreousness ranking of the soft hybrids used in this experiment. Since the correlation between vitreousness and grain density is high and positive (Correa et al., 2002), density can be used as indirect measurement of vitreousness. The soft hybrid AG 1051, used in this study, was the hybrid with the lowest density, among a population of 103 hybrids evaluated by Guimarães (1997). Hybrid AG 4051, the other dent used in this experiment, showed a mean vitreousness at the three maturation stages 0.15 percent units higher than hybrid AG 1051. The soft hybrids used in this study most likely represent the lowest end of vitreousness available in the Brazilian market of corn seeds.

The soft hybrids used in this work were, on average, 35\% less vitreous than the hard ones (Table 3) and showed vitreousness similar to North American dent grains (Correa et al., 2002). These authors, studying 14 dent hybrids at three maturities, found vitreousness values ranging from 42.8 to $48.2 \%$ of the endosperm. In a study conducted in France, a mature dent hybrid showed vitreousness of 48.1\% (Philippeau \& Michalet-Doreau, 1997). In another experiment, Philippeau et al. (1999a) studied six flint hybrids at the mature stage and observed a mean vitreousness value of $71.8 \%$, similar to the value found for flint hybrids in this study. The hybrids used in this work are representative of flint and dent hybrids used in other countries. There is variability in grain vitreousness within the hybrids available in the Brazilian market. Domestic breeding programs aimed at improving corn texture could be developed using materials that already exist in Brazil.

Vitreousness of the hard and soft texture grain increased linearly with advancing maturity, and at all maturity stages was superior in flint grain (Table 3). Flint hybrids at the ED stage were more vitreous than dent at the BL stage, indicating that early harvesting does not allow for the conciliation of planting of flint grain cultivars with harvesting grain of low vitreousness. The daily increase in grain vitreousness as plant maturity progressed was greater in flint hybrids (Figure 1). From the ED to the BL stage, the daily gain in vitreousness of flint hybrids was 0.51 percent units, while in dent hybrids the gain was 0.29. Philippeau \& Michalet-Doreau (1997) also observed greater vitreousness gain per day of progressing maturity in flint grain than in dent grain. In their experiment, as maturity progressed from 22 to 78 days after flowering, vitreousness in a flint hybrid increased 34 percent units, while vitreousness in a dent hybrid increased 21.6. 
Table 3 - Dry matter ruminal degradation in 24 hours of incubation (DEG24), residue at 72 hours of incubation (RES72), vitreousness (Vitre) and percentage of dry matter (\%DM) of grain from two corn hybrids with hard texture (Flint) and two with soft texture (Dent) harvested at the early dent (ED), half milk line (ML), and black layer (BL) maturity stages.

\begin{tabular}{|c|c|c|c|c|c|c|c|c|c|c|c|c|}
\hline & \multicolumn{3}{|c|}{ Flint } & \multicolumn{3}{|c|}{ Dent } & \multirow[b]{2}{*}{ SEM $^{1}$} & \multirow[b]{2}{*}{ Texture } & \multirow[b]{2}{*}{ Maturity } & \multirow[b]{2}{*}{$\mathrm{T}^{*} \mathrm{E}$} & \multirow[b]{2}{*}{$\mathrm{L}$} & \multirow[b]{2}{*}{ Q } \\
\hline & ED & ML & BL & ED & ML & BL & & & & & & \\
\hline & \multicolumn{12}{|c|}{ - $\%$ of DM - } \\
\hline DEG24 & 73.3 & 65.0 & 19.0 & 86.2 & 61.4 & 42.3 & 2.8 & $<0.001$ & $<0.001$ & $<0.001$ & $<0.001$ & $<0.01$ \\
\hline \multirow[t]{2}{*}{ RES72 } & 1.9 & 3.7 & 41.1 & 1.2 & 4.8 & 16.9 & 1.1 & $<0.001$ & $<0.001$ & $<0.001$ & $<0.001$ & $<0.001$ \\
\hline & \multicolumn{12}{|c|}{ of endosperm } \\
\hline \multirow[t]{2}{*}{ Vitre } & 59.9 & 67.0 & 74.2 & 38.2 & 46.9 & 47.9 & 2.7 & $<0.001$ & 0.01 & 0.54 & $<0.01$ & 0.45 \\
\hline & \multicolumn{12}{|c|}{ of grain -} \\
\hline$\% \mathrm{DM}$ & 60.0 & 64.5 & 78.4 & 54.5 & 62.4 & 74.2 & 2.6 & 0.12 & 0.01 & 0.82 & $<0.001$ & 0.20 \\
\hline
\end{tabular}

${ }^{1} \mathrm{SEM}=$ standard error of the mean, Texture $=P$ for grain texture effect, Maturity $=P$ for maturity stage effect, $\mathrm{T}^{*} \mathrm{E}=P$ for the interaction between grain texture and maturity stage, $\mathrm{L}=P$ for the linear contrast of maturity stage, $\mathrm{Q}=P$ for the quadratic contrast of maturity stage.

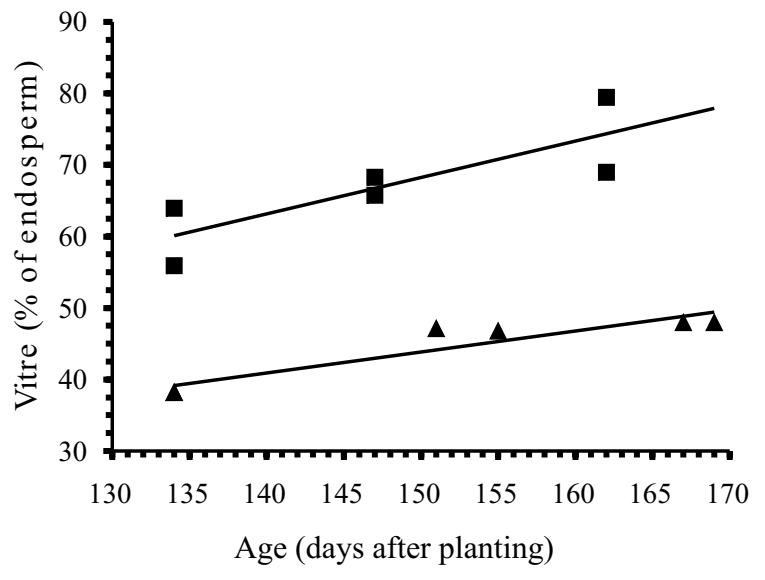

Figure 1 - Vitreousness (Vitre) as a function of plant age in two hard texture $(\boldsymbol{\square})$ and two soft texture $(\boldsymbol{\Delta})$ corn hybrids harvested at the early dent, half milk line and black layer maturity stages. Regressions having Vitre as dependent variable were: $-8.273+0.510$ days after planting, $\mathrm{r}^{2}=$ 0.69 for flint hybrids and $0.033+0.292$ days after planting, $\mathrm{r}^{2}=0.86$ for dent hybrids.

The greater vitrification rate in flint hybrids could be in part related to its greater precocity (Alessi \& Power, 1974). At the ML and BL stages, flint hybrids were, on average, four days earlier than dent hybrids (Table 2). However, at the ED stage, flint and dent hybrids were harvested at the same age. The subjectivity inherent to the visual evaluation of the position of the milk line could explain the similarity in plant age at the earlier harvesting point. Correa et al. (2002) observed negative correlation between vitreousness and plant age at maturity in 14 North American dent hybrids. Planting hybrids with different grain textures could be a strategy to increase the amplitude of the harvesting period at a given maturity stage of the plant.

The percentage of grain DM tended $(P=0.12)$ to be lower in dent grain in comparison to flint grain, and linearly increased as plant reached maturity (Table 3). At the same maturity stage, determined by the position of the milk line, dent corn was about four percent units moister than flint corn. The farinaceous endosperm possesses a less compacted cell structure, where air spaces exist between the starch granules involved by a fine and discontinuous protein matrix, which allows moisture to remain longer in the endosperm. Similar results were found by Philippeau \& Michalet-Doreau (1998), who reported $46.4 \%$ DM content in dent grain and $52.3 \%$ in flint grain, both at the half milk line stage. Philippeau \& Michalet-Doreau (1997) also observed that in plants with $30 \%$ dry matter, DM content of dent and flint grain was $38.7 \%$ and $53.9 \%$, respectively. In the present study, the rate of increase in \%DM with aging of plants was slightly higher in flint than in dent grain (Figure 2). The use of soft hybrids, which possess moister grain than hard hybrids at the same maturity stage, could be advantageous. The potential of the ensiling equipment to physically damage grain could be increased by a higher grain moisture content at harvest time.

Dent corn was more degraded in the rumen than flint corn, and the texture effect on DEG24 and RES72 was marked at the BL maturity stage (Table 3). The smaller ruminal degradation of flint hybrids is probably related to the smaller enzymatic attack to the starch granules because of the greater presence of protein matrix in the endosperm (McAllister et al., 1993). The decrease in DEG24 per day of increase in plant maturity was of $1.30 \%$ in dent, and $1.42 \%$ in flint hybrids (Figure 3 ). There was a strong effect of texture on the size of the undigestible fraction as maturity progressed (Figure 4). Total tract apparent digestibility of starch in dairy cows dropped from 92.2 to $87.7 \%$ as silage maturity progressed from 2/3 milk line to the black layer stage (Bal et al., 1997). When starch ruminal degradation dropped from 60.8 to $34.8 \%$, large intestine starch digestion increased 


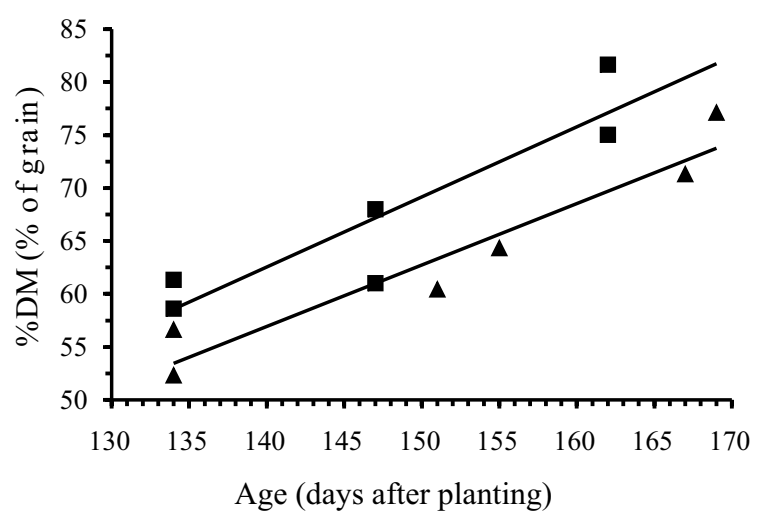

Figure 2 - Grain dry matter content (\%DM) as a function of plant age in two hard texture ( $\boldsymbol{\square})$ and two soft texture $(\boldsymbol{\Delta})$ corn hybrids harvested at the early dent, half milk line and black layer maturity stages. Regressions having \%DM as dependent variable were: $-30.296+0.663$ days after planting, $\mathrm{r}^{2}=0.83$ for flint hybrids and $-24.334+$ 0.581 days after planting, $r^{2}=0.92$ for dent hybrids.

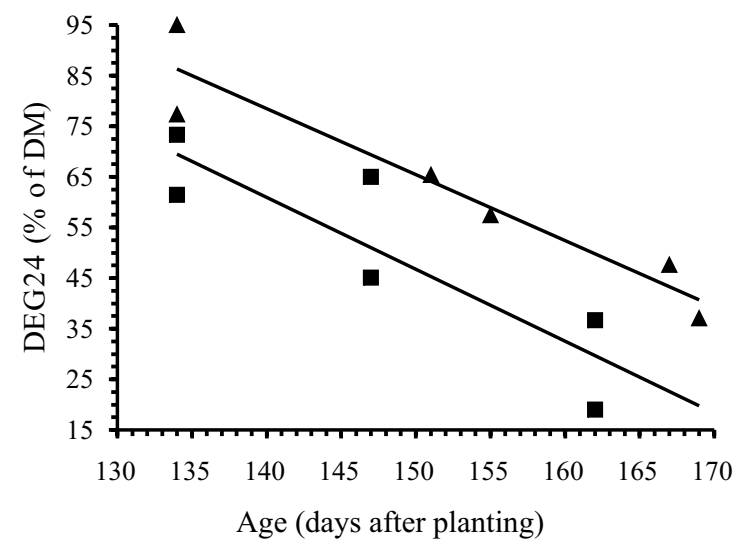

Figure 3 - Dry matter ruminal degradability in 24 hours of incubation (DEG24) as a function of plant age in two hard texture ( $\boldsymbol{\square})$ and two soft texture ( $\boldsymbol{\Delta})$ corn hybrids harvested at the early dent, half milk line and black layer maturity stages. Regressions having DEG24 as dependent variable were: $260.1-1.422$ days after planting, $\mathrm{r}^{2}=0.77$ for flint hybrids and $260.7-1.302$ days after planting, $r^{2}=0.91$ for dent hybrids.

from 13.5 to 28.5\% (Philippeau et al., 1999b). Ensiling flint grain at an advanced maturity stage could result in shifting the site of starch digestion from the rumen to the large intestine, leading to fecal loss of microbial protein produced during fermentation (Huntington, 1997). Since corn grain cultivated in Brazil is predominantly hard-textured (Cruz et al., 2003), estimates of its nutritional value and recommendations for dietary carbohydrate content reported from other countries may require adjustments before being used in Brazil. Questioning the international research in these areas is necessary, providing support for the geographical argument when research hypotheses are to be formulated.

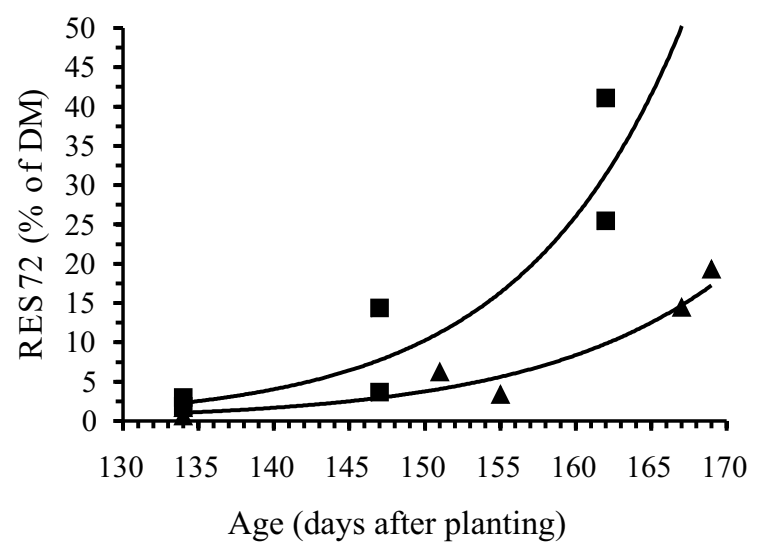

Figure 4 - Dry matter residue at 72 hours of ruminal incubation (RES72) as a function of plant age in two hard texture $(\boldsymbol{\square})$ and two soft texture $(\boldsymbol{\Delta})$ corn hybrids harvested at the early dent, half milk line and black layer maturity stages. Regressions having RES72 as dependent variable

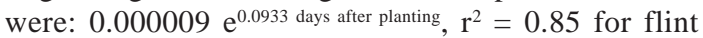
hybrids and $0.000022 \mathrm{e}^{0.0803 \text { days after planting }}, \mathrm{r}^{2}=0.89$ for dent hybrids.

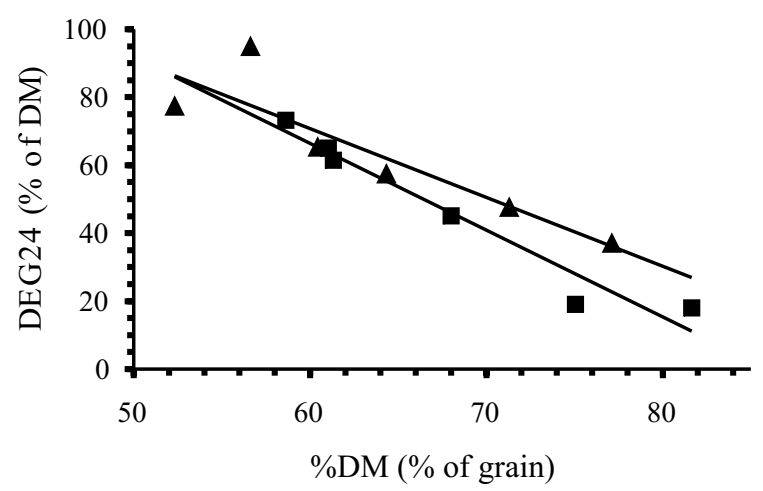

Figure 5 - Dry matter ruminal degradability in 24 hours of incubation (DEG24) as a function of grain dry matter content (\%DM) in two hard texture ( $\boldsymbol{\square})$ and two soft texture $(\boldsymbol{\Delta})$ corn hybrids harvested at the early dent, half milk line and black layer maturity stages. Regressions having DEG24 as dependent variable were: $219.4-2.550 \% \mathrm{DM}, \mathrm{r}^{2}=$ 0.95 for flint hybrids and $192.0-2.021 \% \mathrm{DM}, \mathrm{r}^{2}=0.81$ for dent hybrids.

Since the milk line is a subjective indicator of maturity (Bal at al., 1997), \%DM was also correlated with DEG24 (Figure 5). Decrease in DEG24 per unit increase in $\% \mathrm{DM}$ in the grain was $2.55 \%$ for flint hybrids and $2.02 \%$ for soft hybrids. The texture effect on DEG24 was apparently more striking when $\% \mathrm{DM}$ in the grain was above $65 \%$. The texture effect on ruminal starch degradability may be important in farms using high moisture corn as a concentrate feedstuff, since these are normally harvested at grain dry matter content values above those capable of inducing a marked texture effect on ruminal degradability. 
Assuming that ensiling flint grain should be performed at earlier plant maturity stages to avoid reductions in ruminal degradability (Table 3), differences in the rate of maturation between flint and dent grain (Table 2) and in the rate of decrease in rumen degradability as plant age increases (Figures 3 and 4) could be used to expand the ensiling period. In such cases, dent hybrids would be the choice in late harvest situations. Planting soft-textured corn would allow greater flexibility in the definition of harvest maturities, minimizing losses of nutritional value due to late ensiling. Using dent hybrids would also be advantageous when the ensiling process is slow or the equipment is poorly efficient in processing the grain. In these cases, the use of soft-textured grains may reduce the passage of intact grain throughout the digestive tract of bovine (Buck et al., 1969).

As maturity progressed, the linear increase in $\% \mathrm{DM}$ and Vitre was reflected as a quadratic decrease in DEG24 and as a quadratic increase in RES72 (Table 3). These data suggest that the proportion of vitreous endosperm is not the only determinant of corn grain ruminal degradability. Feed hydration may also be important for their degradability in the rumen (Van Milgen et al., 1993). It is possible that the joint effect of grain texture and moisture on ruminal degradability acts as a potentiator, resulting in a proportionally greater decrease in degradability at plant maturity stages that conciliate high vitreousness with low moisture content. Defining the factors that act on the ruminal corn starch degradability would be important for the selection of corn hybrids with the ability of maintaining high digestibility at more advanced stages of plant maturity.

\section{CONCLUSION}

Dry matter ruminal degradation of hard and soft texture corn grain decreased as plant age progressed. A marked decrease in ruminal degradability occurred when the hybrid progressed from half milk line to black layer stage. The negative effect of maturity on ruminal degradability was more striking on flint hybrids, of greater vitreousness. Use of dent hybrids, compared to flint hybrids, may result in smaller relative decrease in ruminal starch digestion in situations of late grain harvesting.

\section{REFERENCES}

ALESSI, J.; POWER, J.F. Effects of plant population, row spacing, and relative maturity of dryland corn in the northern plains. I. Corn forage and grain yield. Agronomy Journal, v.66, p.316-319, 1974.

ALLEN, M.S.; OBA, M.; CHOI, B.R. Nutritionist's perspective on corn hybrids for silage. In: SILAGE: FIELD TO FEEDBUNK, Hershey, 1997. Proceedings. Ithaca: Northeast Regional Agricultural Engineering Service-99, 1997. p.25-36.
BAL, M.A.; COORS, J.G.; SHAVER, R.D. Impact of maturity of corn for use as silage in the diets of dairy cows on intake, digestion, and milk production Journal of Dairy Science, v.80, p.2497-2503, 1997.

BUCK, G.R.; MERRILL, W.G.; COPPOCK, C.E.; SLACK, S.T. Effect of recutting and plant maturity on kernel passage and feeding value of corn silage. Journal of Dairy Science, v.52, p.1617-1632, 1969.

CORREA, C.E.S.; SHAVER, R.D.; PEREIRA, M.N.; LAUER, J.G.; KOHN, K. Relationship between corn vitreousness and ruminal in situ degradability. Journal of Dairy Science, v.85, p.3008-3012, 2002.

CRUZ, J.C.; CORRÊA, L.A.; PEREIRA FILHO, I.A.; FALCÃO, F.T.; VERSIANI, R.P. Cultivares de milho disponíveis no mercado de sementes do Brasil para a safra 2003/04. http://www.cnpms.embrapa.br/ cultivares/index.html. (10/11/2003).

DOMBRINK-KURTZMAN, M.A.; BIETZ, J.A. Zein composition in hard and soft endosperm of maize. Cereal Chemistry, v.70, p.105-108, 1993.

GUIMARÃES, V.D. Fatores que controlam a dureza do endosperma do grão de milho. Viçosa, 1997. 67p. Dissertação (Mestrado) - Universidade Federal de Viçosa.

HUNTINGTON, G.B. Starch utilization by ruminants: From basics to the Bunk. Journal of Animal Science, v.75, p.852-867, 1997.

JOHNSON, L.; HARRISON, J.H.; HUNT, C.; SHINNERS, K.; DOGGETT, C.G.; SAPIENZA, D. Nutritive value of corn silage as affected by maturity and mechanical processing: A contemporary review. Journal of Dairy Science, v.82, p.2813-2825, 1999.

KOTARSKI, S.F.; WANISKA, R.D.; THURN, K.K. Starch hydrolysis by the ruminal microflora. Journal of Nutrition, v.122, p.178-190, 1992.

McALLISTER, T.A.; PHILLIPPE, R.C.; RODE, L.M.; CHENG, K.J. Effect of the protein matrix on the digestion of cereal grains by ruminal microorganisms. Journal of Animal Science, v.71, p.205-212, 1993.

PHILIPPEAU, C.; MICHALET-DOREAU, B. Influence of genotype and stage of maturity of maize on rate of ruminal starch degradation. Animal Feed Science and Technology, v.68, p.25-35, 1997.

PHILIPPEAU, C.; MICHALET-DOREAU, B. Influence of genotype and ensiling of corn grain on in situ degradation of starch in the rumen. Journal of Dairy Science, v.81, p.2178-2184, 1998.

PHILIPPEAU, C.; LE DESCHAULT DE MONRENDON, F.; MICHALETDOREAU, B. Relationship between ruminal starch degradation and physical characteristics of corn grain. Journal of Animal Science, v.77, p.238-243, 1999a.

PHILIPPEAU, C.; MARTIN, C.; MICHALET-DOREAU, B. Influence of grain source on ruminal characteristics and rate, site, and extent of digestion in beef steers. Journal of Animal Science, v.77, p.1587-1596, 1999b.

PRATT, R.C.; PAULIS, J.W.; MILLER, K.; NELSEN, T.; BIETZ, J.A. Association of zein classes with maize kernel hardness. Cereal Chemistry, v.72, p.162-167, 1995.

ROBUTTI, J.L.; HOSENEY, R.C.; WASSOM, C.E. Modified opaque-2 corn endosperms. II. Structure viewed with a scanning electron microscope. Cereal Chemistry, v.51, p.173-180, 1974.

ROONEY, L.W.; PFLUGFELDER, R.L. Factors affecting starch digestibility with special emphasis on sorghum and corn. Journal of Animal Science, v.63, p.1607-1623, 1986.

SAS INSTITUTE INC. SAS/STAT User's Guide, 6.03 ed. Cary: SAS Institute Inc., 1988. 1028p.

VAN MILGEN, J.; BERGER, L.L.; MURPHY, M.R. An integrated, dynamic model of feed hydration and digestion, and subsequent bacterial mass accumulation in the rumen. British Journal of Nutrition, v.70, p.471483, 1993.

WATSON, S.A. Corn marketing, processing, and utilization. In: SPRAGUE, G.F.; DUDLEY, J.W. (Ed.) Corn and corn improvement. Madison: ASA, 1988. p.881-940.

Received July 14, 2003

Accepted April 23, 2004 